\title{
artigos
}

DOI: 10.11606/issn.2318-8855.v6i6p67-104

\section{Identidade romana no Império Bizantino: novas perspectivas de um problema de alteridade $^{1}$}

Guilherme Welte Bernardo*

Resumo: A identidade romana dos bizantinos é frequentemente minimizada pelos historiadores, seja compreendendo-a por meio da cristã, seja enxergando-a como uma "fachada" de uma identidade perene helênica, desconectando essencialmente os bizantinos dos antigos romanos. $\mathrm{O}$ próprio uso do termo "bizantino" para se referir àquela civilização é moderno e surge da negação de sua reivindicação identitária, originando-se em antigos conflitos medievais. Essas perspectivas, contudo, estão sendo amplamente contestadas e uma reavaliação da romanidade bizantina parece estar em curso. O presente artigo visa contextualizar e apresentar os problemas que cercam essas discussões e os caminhos que as têm norteado, abordando temas como a "origem" do Império Bizantino e seus problemas de periodização, a negação de sua romanidade e a imputação de nomenclaturas artificiais, o "bizantinismo" enquanto problema de alteridade e os significados políticos dessa identidade, destacando a tese de Anthony Kaldellis de Bizâncio como o estado-nação medieval dos romanos.

Palavras-chaves: Império Bizantino; Identidade Romana; Historiografia.

\section{Introdução}

Comentando os problemas da historiografia gibboniana sobre Bizâncio, Steven Runciman, renomado historiador britânico do século XX, afirma que Edward Gibbon (1737-1794), autor de The

\footnotetext{
${ }^{1}$ Este artigo é uma versão revisada do trabalho de conclusão de curso desenvolvido em 2017 na Universidade Veiga de Almeida (UVA) sob orientação da Prof. a Dr. a Patrícia Domingos Woolley Cardoso, a quem sou enormemente grato. Também sou grato aos pareceristas da Revista Epígrafe que fizeram críticas construtivas a este artigo, ajudando-o a tomar esta forma final.

* Graduado em História pela Universidade Veiga de Almeida (UVA). E-mail para contato: g.welte@outlook.com.
} 


\section{artigos}

Guilherme Welte Bernardo

History of the Decline and Fall of the Roman Empire (1776-1778), foi influenciado mais por seu "clima intelectual" do que pelas limitações de fonte então disponíveis (RUNCIMAN, 1976, p. 105). Todo historiador contemporâneo compreende com naturalidade as implicâncias dessa afirmação. É possível dizer que o contexto intelectual de uma época integra um dos elementos que constituem o lugar social do historiador, uma vez que "Toda pesquisa historiográfica se articula com um lugar de produção socioeconômico, político e cultural" (CERTEAU, 2008, p. 47). Consequentemente, a maneira como o passado é estudado está sempre condicionada a paradigmas e a tensões contemporâneos ao historiador.

O Império Bizantino tem sido estudado e interpretado ao longo do tempo por meio das lentes ocidentais. Cabem ao Ocidente os créditos por lançar as bases do ramo multidisciplinar de estudos sobre Bizâncio. Já no século XVI, o humanista alemão Hieronymus Wolf foi o responsável por realizar a primeira grande coleção de fontes históricas bizantinas, o Corpus Historiae Byzantinae, publicado em 1557, relativamente pouco tempo após o fim do império. Infelizmente, esse interesse veio carregado de preconceitos gerados por conflitos de longa data que foram acentuados e difundidos, criando artificialidades que permanecem até os dias de hoje e que se apresentam como verdadeiros desafios para os historiadores.

Estudos recentes têm reinterpretado a partir de uma nova abordagem esse império milenar e sua identidade. Neste presente artigo, buscou-se oferecer um panorama geral sobre o contexto desses problemas e as principais novas perspectivas em resposta a eles.

\section{Identidade imputada}

Define-se frequentemente o que chamamos de Império Bizantino como a continuação histórica do Império Romano Oriental até o ano de 1453, quando, já extremamente enxuto, sua capital foi conquistada pelo Império Otomano. No entanto, os termos "Império Bizantino" e "Império Romano Oriental" são construções historiográficas modernas que, ainda que úteis, possuem problemas se empregados sem a devida reflexão terminológica. 


\section{artigos}

Identidade romana no Império Bizantino: novas perspectivas de um problema de alteridade

De acordo com Kaj Sandberg, é extremamente negligenciado entre historiadores e classicistas o fato que nunca existira uma divisão formal do Império Romano entre um "Império Romano Ocidental" e um "Império Romano Oriental", seja no simbólico ano de 395, ${ }^{2}$ que marca a morte de Teodósio I, ou posteriormente no século V. As duas administrações regionais formavam um único corpo social e político governado por dois imperadores corregentes (SANDBERG, 2008, p. 200-202). ${ }^{3}$ Para Lucy Grig e Gavin Kelly, sobrestimar esta divisão "[...] ignora não somente a continuidade retórica da unidade, mas também o fato de que o império estivera dividido pela maior parte dos cem anos anteriores" (GRIG e KELLY, 2012, p. 17, tradução nossa). Desde já, essas conclusões nos obrigam a questionar a definição de Bizâncio como a continuação desse "Império Romano Oriental" e não do próprio Império Romano. Embora o recorte seja útil para entender o contexto imperial naquela região, não se pode estender sua aplicação e afirmar com base nele que Bizâncio é a continuação de uma coisa que não existiu. Sandberg lembra que termos como esse são convencionais e refletem a árdua tarefa de organizar os dados históricos, mas, "[...] embora artificiais em teoria, na prática, convenções desse tipo influenciam percepções dos processos históricos e, de fato, os próprios caminhos que os estudiosos selecionam e apresentam seu material" (SANDBERG, 2008, p. 199, tradução nossa).

Quando a cidade de Roma foi conquistada em 476, o Império Romano passou a ter novamente um único imperador, o que já acontecera anteriormente em alguns momentos após 395, especialmente nas décadas de 450 e 460 . Segundo Sandberg, "É bem claro que todo o Império, pelo menos formalmente, foi governado a partir de Constantinopla durante esses interregnos" (SANDBERG, 2011, p. 208-209). Se esse evento for contextualizado desta forma, o que observamos em 476 é a perda das províncias ocidentais do Império para outros povos, não a apocalíptica e anacrônica "Queda do Império Romano", como descrita muitas vezes em obras historiográficas e

\footnotetext{
${ }^{2}$ A não ser quando indicado, todas as datas neste artigo são d.C.

${ }^{3}$ Segundo Sandberg (2008, p. 206-207), a unidade não era uma ficção vazia se vista a partir dos documentos legais e administrativos. Funcionários chaves como os praefecti urbi de Roma e os praefecti praetorio respondiam a ambos os imperadores. A unidade do Império foi um aspecto proeminente e onipresente em todo discurso político mesmo após o fim da dinastia teodosiana. Além disso, ao longo do século $V$, alguns imperadores ocidentais foram apontados pelos imperadores em Constantinopla, demonstrando essa unidade.
} 


\section{artigos}

Guilherme Welte Bernardo

infundida na cultura popular. A continuidade do Império no Oriente não afetava a romanidade do mesmo, pois esta já não era mais dependente da cidade de Roma e dos povos itálicos originais. ${ }^{4}$ Como afirma Jeroen W. P. Wijnendaele, "[...] de um ponto de vista constitucional, esse chamado Império Bizantino ainda era o Império Romano. Assim era para os seus habitantes como para os seus vizinhos" (WIJNENDAELE, 2011, p. 44, tradução nossa). Após dominar Roma e depor o jovem Rômulo Augústulo, ${ }^{5}$ considerado um usurpador no Oriente, Odoacro escreve a Zenão, o imperador em Constantinopla, a fim de colocar-se sob sua autoridade (LAFFERTY, 2013, p. 4). Também os demais logo firmaram alianças com o imperador em Constantinopla, considerando-se como reis clientes dentro de uma relação de suserania (LOUTH, 2005, p. 93). John Moorhead afirma que "Por mais dramáticos que esses eventos tenham sido, eles não constituem uma separação definitiva dos caminhos entre o Ocidente pós-romano e o que nós podemos chamar agora de 'Oriente Bizantino'" (MOORHEAD, 2005, p. 118, tradução nossa). O autor cita com alguns detalhes atividades de trocas comerciais, apontamento de cônsules para o Ocidente, a forte presença de diplomatas no Mediterrâneo, longas viagens diplomáticas na corte de Teodorico, a enxurrada de médicos orientais no Ocidente, atividades de intelectuais ocidentais em Constantinopla, manuscritos latinos sendo copiados em Constantinopla e, gregos, em Ravena, e acrescenta que

[...] apesar do advento dos novos detentores de poder no Ocidente, os novos governantes estavam lá afiados para representar a si mesmos como de algum modo subservientes aos imperadores romanos que ainda governavam em Constantinopla. Teodorico, o Ostrogodo, escreveu ao imperador Anastácio que "nosso reino é uma imitação do seu... uma cópia do único Império", e Sigismundo, o Burgúndio, informou que, enquanto dava a aparência de governar seu povo, acreditava ser ele

\footnotetext{
${ }^{4}$ Segundo Wijnendaele (2011, p. 42), a sobrevivência do Império Romano apartado de seu povo e território central original era possível porque cada vez mais quem o dominava eram os provinciais da Gália, das províncias danúbias e do Oriente grego. Segundo o autor, esse é um fenômeno singular na história ocidental, mas é precisamente o que aconteceu com o Império Romano de Diocleciano em diante. O foco da gravidade do Império muda, e Roma e os povos de língua latina não mais detêm o domínio de seu governo.

5 "Significantemente, a deposição de Rômulo Augústulo causou notavelmente pouca agitação entre as fontes contemporâneas. Foi, nas palavras do historiador italiano Arnaldo Momigliano, a 'silenciosa queda de um Império'" (LAFFERTY, 2013, p. 3, tradução nossa). Cf. MOMIGLIANO, 1973.
} 


\section{artigos}

Identidade romana no Império Bizantino: novas perspectivas de um problema de alteridade mesmo meramente um soldado do imperador. Nesse e em outros aspectos, o Ocidente pós-romano permanecia firmemente uma parte do mundo romano (MOORHEAD, 2005, p. 119, tradução nossa). ${ }^{6}$

Sob essa ótica, torna-se evidente que a tradicional definição dada no começo do texto é problemática se esses elementos forem negligenciados. Assim, as seguintes questões poderiam ser levantadas: "Bizâncio" deve ser compreendido como um período da história romana? Se sim, isso significaria falar de um Império Romano que perdurou até 1453, tornando-o um dos mais longevos impérios da história. Por que, então, empregar o termo "bizantino" para essa sociedade?

Os chamados bizantinos se autodenominavam romanos ('P $\omega \mu \alpha \hat{i} o l)$ e chamavam seu estado de

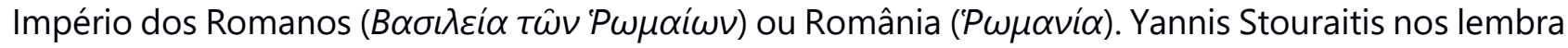
que "bizantino" é um terminus technicus acadêmico desenvolvido no começo da modernidade que não corresponde à autodesignação normativa dessa sociedade. Segundo o autor, essa abordagem impõe ao historiador moderno o viés latente de que a identidade coletiva dessa sociedade deve ser chamada e, portanto, entendida de maneira diferente (STOURAITIS, 2014, p. 175). Isso remete a uma discussão antiga entre perspectivas que interpretam a relação entre Roma e Bizâncio em termos de continuidade ou descontinuidade.

A primeira perspectiva enxerga uma ruptura tão grande nos rumos do Império que não é mais possível chamá-lo e entendê-lo como romano. Embora tenha ganhado contornos mais definidos no século XIX, o descontinuísmo possui bases intelectuais anteriores a profissionalização da disciplina. Em 1916, o historiador belga Paul Van Den Ven (1879-1973) colocou as seguintes questões a partir de perspectiva descontinuísta:

[...] é evidente que o assunto em questão não é meramente a escolha judiciosa de um nome, mas sim uma consideração da própria essência das coisas sob esse nome. O Império Romano é realmente o Império Romano no século $X V$, apesar de suas numerosas transformações? Ele poderia ter permanecido por um período tão longo

\footnotetext{
${ }^{6}$ Para a ideia de continuidade e transformações lentas na Antiguidade Tardia, cf. MOOHEAD, 2013. Complementarmente, cf. BROWN, 1989; CAMERON, 2012.
} 


\section{artigos}

Guilherme Welte Bernardo

a mesma criatura viva cuja natureza não muda em diferentes períodos de sua vida? As transformações pelas quais passou, no quarto século e posteriormente, não permearam tão profundamente que é apropriado dar-lhe outro nome que corresponda à sua nova natureza? [...] (VEN, 1916, p. 306, tradução nossa).

O argumento sobre a descontinuidade é antes de tudo uma idealização do que Roma ou o Império Romano são. Para ser romano, é preciso cumprir certos requisitos, como ter sua centralidade no Ocidente, falar latim e ser pagão. Não cumprindo, esse império oriental, helenófono e cristão é uma outra coisa e, como tal, deve ser chamado e entendido de forma diferente. Ele é o reflexo de uma época em que historiadores e outros intelectuais estavam fixados em demarcações essencialistas e obcecados pelas origens das coisas. ${ }^{7}$

A perspectiva continuísta ecoa a Edward Gibbon, que, embora sustentasse certo desdém a Bizâncio, termina sua famosa obra com a queda de Constantinopla em 1453. O historiador irlandês J. B. Bury (1861-1927) pode ser considerado o defensor mais pertinaz dessa visão. Para os historiadores que a sustentam, é possível falar de um Império Romano que perdurou até 1453, mesmo que mudanças profundas tenham ocorrido nesse meio tempo:

Em seu A History of the Later Roman Empire from Acadius to Irene (395 A.D to 800 A.D.), Bury expressa visões robustas sobre questões de periodização e terminologia. Ele alegava que a história do Império Romano tardio foi "constantemente incompreendida" e, seu caráter, "deturpado" devido ao uso de "títulos incorretos e enganosos". Na visão de Bury, o "fato essencial" de que "o velho Império Romano não deixou de existir até o ano de 1453" foi obscurecido "ao aplicar o nome 'bizantino' ou o nome 'grego' ao Império em seus estágios tardios", especialmente porque os historiadores que usaram esses termos foram "não muito consistentes ou muito precisos quanto à data em que o 'Império Romano' termina e o 'Império Bizantino' começa". De fato, como o Império Bizantino nunca existiu, pode-se afirmar

\footnotetext{
${ }^{7}$ Para uma discussão sobre periodização, cf. BESSERMAN, 1996; LE GOFF, 2017; TOUGHER, 2017.
} 


\section{artigos}

Identidade romana no Império Bizantino: novas perspectivas de um problema de alteridade que "bizantino é uma palavra perigosa quando usada em um sentido político" (TOUGHER, 2017, p. 40-41, tradução nossa).

Mesmo escrevendo no final do século XIX, Bury soa vanguardista em suas propostas. Relativamente recente, essa perspectiva vem impactando o campo de diferentes formas. Os estudos que trabalham com a ideia de "continuidade" avançaram, possibilitando uma leitura mais ampla da sociedade bizantina. É possível dizer que atualmente a ênfase se deslocou para o processo que transformou a antiga Roma no Bizâncio medieval, explorando as conexões entre as duas civilizações por meio das continuidades e descontinuidades. ${ }^{8}$ Ademais, o termo "bizantino", apesar das críticas de Bury, permanece como uma ferramenta útil de delimitação para se estudar o Império Romano em sua fase medieval, helenófona e cristã ortodoxa. ${ }^{9}$

A periodização demonstra as dificuldades intrínsecas dessa delimitação. Qualquer recorte escolhido para marcar o "nascimento" do Império Bizantino é simbólico. ${ }^{10}$ Como não existiu o "início" do Império Bizantino, não há consenso:

A historiografia francesa tende a argumentar que Bizâncio começa com Constantino, mas há também a visão de que Bizâncio propriamente só começa no século VII, com a ruptura provocada pelo nascimento do Islã e as concomitantes conquistas árabes iniciais nas quais grande parte dos territórios orientais do Império foi perdida. Isso também está associado a uma reformulação do Império Bizantino ao longo de linhas mais obviamente gregas e com significativa mudança institucional. Outros argumentaram que a era crítica da transformação foi o prolongado reinado do

\footnotetext{
${ }^{8} \mathrm{Cf}$, por exemplo, as seguintes abordagens, não necessariamente concordantes ou sobre a mesma temática: CAMERON, 2012; KALDELLIS, 2007, 2015b; LEE, 2013; STOURAITIS, 2014, 2017.

${ }^{9}$ Recentemente, Gill Page $(2008$, p. 6) propôs "romanos bizantinos" como uma alternativa ao famigerado termo. Anthony Kaldellis (2015a), o principal revisionista na questão identitária bizantina, não vê necessidade em seu abandono, mas diz que é preciso que entendamos melhor ao que ele se refere.

10 Para Bizâncio como um clássico problema de periodização, cf. TOUGHER, 2017, p. 39-41.
} 


\section{artigos}

Guilherme Welte Bernardo

próprio Justiniano I (527-565) e que no decorrer do período de seu governo a antiga Roma deu lugar a Bizâncio medieval (TOUGHER, 2017, p. 40, tradução nossa). ${ }^{11}$

Embora úteis para demarcar o início de transformações importantes, essas datas e acontecimentos conjecturais não devem conduzir a uma leitura anacrônica de que Constantino ou Justiniano estavam fundando um novo império. Ambos foram, até o último momento de suas vidas, imperadores romanos.

Para entendermos porque não chamamos os bizantinos de romanos, é preciso compreender o processo de ruptura entre o Ocidente e o Oriente causado por conflitos políticos e religiosos ao longo da Idade Média. Alguns eventos são importantes, como a querela iconoclasta no século VIII; a intervenção carolíngia contra os lombardos na Itália por Pepino, o Breve (714-768); a forjada "Doação de Constantino", com claro intuito de excluir os bizantinos da península e estabelecer um poder temporal ao Papa de Roma; a coroação de Carlos Magno como imperador em 800 pelo papa Leão III; os conflitos sobre as missões entre os eslavos no século IX; a disputa em torno da elevação de Fócio I a Patriarca de Constantinopla em 858, o que alimentou ainda mais o conflito sobre o filioque; a correspondência de Luís II com Basílio I em 871, reacendendo o discurso que o poder imperial origina-se da Igreja de Roma e não "do senado e do povo"; a restauração imperial em 962 por Oto I e os conflitos sobre os territórios no sul da Itália e o título imperial; a troca de excomunhões mútuas entre o patriarca Miguel Cerulário e os legados papais em 1054; o desastroso "Massacre dos Latinos" em Constantinopla em 1182; e a incursão dos cruzados por Bizâncio, somada ao também desastroso saque de Constantinopla em $1204 .{ }^{12}$

As relações entre Ocidente e Oriente passaram a ser de um grande estranhamento. As tentativas de recriar o Império Romano no Ocidente e o progressivo desdém ao imperador em

\footnotetext{
${ }^{11}$ Cf. as referências dadas pelo autor: CAMERON, 2014, p. 5; HALDON, 1990; CAMERON, 1985.

12 Para uma síntese das relações, cf. BALARD, 2006; NICOL, 1967. Para Carlos Magno e Bizâncio, cf. BARBERO, 2004, p. 89101. Para Luís II e Bizâncio, cf. RICHÉ, 1993, p. 179-189. Para o contexto do Massacre, cf. NICOL, 1992, p. 104-123. Para o Papado e Bizâncio, cf. SIECIENSKI, 2017, p. 195-326.
} 


\section{artigos}

Identidade romana no Império Bizantino: novas perspectivas de um problema de alteridade

Constantinopla foram refletidos na maneira como os ocidentais passaram a caracterizar os orientais. Segundo Han Lamers,

Chamar os bizantinos de gregos ao invés de romanos tem uma longa história no Ocidente latino, regressando ao século IX. Após o Papa Leo III ter coroado Carlos Magno como Imperador dos Romanos em 800, os latinos começaram a minar as reivindicações romanas dos bizantinos. Enquanto os próprios bizantinos nunca pararam de chamar a si mesmos de romanos, as fontes ocidentais, da Idade Média em diante, refletem um viés anti-bizantino que negava seu legado romano chamando-os de gregos. A ideia por baixo era que a coroação de Carlos Magno não implicou numa divisão do Império Romano (a divisio imperii) nem numa renovação do Império ocidental (a renovatio imperii), mas numa transferência do imperium Romanum dos gregos ao Ocidente (o translatio imperii) (LAMERS, 2016, p. 65, tradução nossa).

Os olhares conflituosos mútuos ficam bem explícitos na troca de correspondências (e de ofensas) entre o papa Nicolau I e o imperador Miguel III em 865. Este último enviara uma carta ao papa, infelizmente perdida, chamando a língua latina de "bárbara" e "cita". Em sua resposta ao "Imperador dos Gregos", Nicolau insinua que é melhor que ele então comece a se intitular "Imperador dos Bárbaros" (FÖGEN, 1996, p. 19-22). Numa missão em Constantinopla em 968, o embaixador italiano Liutprando de Cremona relata que, "como para o aumento de suas calamidades", chegara à cidade uma carta do papa João XIII se referindo a Nicéforo II Focas como "Imperador dos Gregos" e a Oto I como "Augusto Imperador dos Romanos". A ira foi tanta que os mensageiros papais foram lançados à prisão (CREMONA, 2007, p. 267-269).

\section{Um problema de alteridade}

Segundo Han Lamers, os historiadores italianos do século XV adotaram a prática de chamar os bizantinos de "gregos" e assim perpetuaram essa tradição ocidental. Em alguns casos, os bizantinos pré-carolíngios eram coletivamente chamados de romanos, mas de modo geral o que prevalecia era a denominação de gregos (LAMERS, 2016, p. 65-66). O interesse dos humanistas era de creditar a si 


\section{artigos}

Guilherme Welte Bernardo

próprios como verdadeiros herdeiros da herança romana, que seria latina, não grega. "Durante o século XV, a ideia de que os italianos eram os justos herdeiros culturais da Roma Antiga era citada e adotada, com diferentes ênfases, por humanistas importantes tais como Salutati, Bruni, Valla e Sabellico" (LAMERS, 2016, p. 67, tradução nossa). ${ }^{13}$

No século XVII, os alemães começaram a se interessar por Bizâncio. Podemos pensar em duas prováveis motivações: a ameaça do poderoso Império Otomano na Europa Central e Meridional (em 1526 anexaram a maior parte de Hungria e em 1529 cercaram Viena) e os conflitos denominacionais entre os protestantes e o catolicismo romano (REINSCH, 2016, p. 44). Por volta de 1551, Hieronymus Wolf, humanista de profundo conhecimento do grego e do latim, estabelecera-se como secretário da biblioteca de Johann Jakob Fugger. Os Fuggers, que estavam envolvidos em trocas comerciais entre os impérios Otomano e Habsburgo, possuíam interesse em extrair da história bizantina algo que pudesse oferecer vantagem em relação aos otomanos. Wolf foi então encarregado de traduzir algumas obras, embora seu desdém pelos bizantinos fosse claro. Segundo Diether Reinsch, no Praefatio escrito em 1559 para uma parte do Corpus publicada em 1562, o humanista alemão

[...] não se cansou de apontar para a sua atualidade política e para a possibilidade de lê-lo para aprender com os erros cometidos pelos bizantinos, que são pintados por Wolf nas cores mais sombrias. Os imperadores no exercício de seu ofício, assim Wolf informa seus leitores como resultado de sua leitura, eram completamente desinteressados e estupidamente mesquinhos quando as despesas necessárias eram necessárias, mas pródigos em gastos não necessários. As guerras civis eram a ordem do dia; altos funcionários e oficiais militares eram perniciosos e tomavam decisões arbitrárias; o clero era ignorante e brigava por vaidades; as pessoas eram arrogantes e fracas; todas as fileiras sociais perpetraram os crimes mais odiosos. Os turcos, ao contrário, mostraram fidelidade, bravura e clemência; suas virtudes foram louvadas

\footnotetext{
${ }^{13}$ Os intelectuais bizantinos que migraram para o Ocidente foram recebidos como gregos. Isso, no entanto, não se dava de forma negativa, mas positiva e apreciativa. "Embora Petrarca tivera uma visão predominantemente negativa sobre os gregos de seu tempo, a geração de Guarino de Verona e Leonardo Bruni era filelena e admirava profundamente Manuel Crisoloras em particular" (LAMERS, 2016, p. 72, tradução nossa). Para o autor, isso ajuda a explicar porque eles aceitaram essa identificação e deixaram de lado estratégias alternativas para apaziguar as diferenças, como dar ênfase a herança romana compartilhada. (LAMERS, 2016, p. 72).
} 


\section{artigos}

Identidade romana no Império Bizantino: novas perspectivas de um problema de alteridade mesmo por seus inimigos. De tudo isso, assim afirmou Wolf, deduziu que os turcos eram muito mais dignos de soberania do que os bizantinos. Em vez de sentir pena deles, ficou surpreso que essa escória humana criminosa ['faex ac sentina'] pode manter-se firme por tanto tempo e não fora subjugada antes. (REINSCH, 2016, p. 51, tradução nossa).

Wolf foi o primeiro a cunhar o termo "bizantino" (em referência à antiga Bizâncio, cidade sobre a qual Constantinopla foi edificada), uma vez que caracterizá-lo como "romano" estava fora de questão, e, gradualmente, "grego" significava somente aquilo relativo à história e à cultura da Grécia Antiga, às quais Wolf nutria muito mais apreço (STATHAKOPOULOS, 2014, p. 204; REINSCH, 2016, p. 46). Aqui, assim como com os italianos, temos, para usar a expressão de Shaun Tougher, uma "imposição retrospectiva" de um rótulo temporal unificador estranho àquela sociedade (TOUGHER, 2017, p. 39-40), além dos reducionismos que transformam Bizâncio, uma civilização milenar, num corpo monolítico pouco interessante a não ser para servir de exemplo aos ocidentais. Nos séculos XVII e XVIII, os franceses, por meio da corte do Luís XIV, foram os responsáveis por difundir o termo ao retomarem o projeto iniciado pelos Fuggers e realizarem até aquele momento a maior empreitada de reunião e tradução (para o latim) de manuscritos bizantinos, conhecidos como Corpus Scriptorum Historice Byzantince ou Byzantine du Louvre, publicados a partir da década de 1640 até 1711. Du Cange (1610-1688) foi uma figura chave nesse reavivamento francês e na consolidação tanto do termo quanto do campo (STATHAKOPOULOS, 2014, p. 205). ${ }^{14}$

Assim, Bizâncio se apresenta como um curioso problema de alteridade. Segundo Dimiter Angelov, a partir das Cruzadas, diversos estereótipos baseados em percepções romanas da Antiguidade em relação aos gregos foram usados em relação aos bizantinos. Eles foram assim considerados como pérfidos, traiçoeiros, servis, afeminados e indispostos a guerra. Esses estereótipos persistiram nas tradições intelectuais ocidentais após o fim do Império, entrelaçandose posteriormente com as percepções modernas iluministas. Com o advento do iluminismo, o Império foi sintetizado como sinônimo de autoritarismo, decadência, superstição e vaidades, em

\footnotetext{
14 Para Du Cange e Bizâncio, cf. SPIESER, 2000.
} 


\section{artigos}

Guilherme Welte Bernardo

suma, o mundo pelo qual se opunham (ANGELOV, 2013, p. 7-9). ${ }^{15}$ Ainda hoje, entradas obscuras em dicionários e no vocábulo político e intelectual continuam manifestando essa essencialização. ${ }^{16}$ Angelov define "bizantinismo" como "[...] um entendimento negativo e essencialista de uma civilização medieval que a coloca em categorias analíticas rigorosas a partir de um ponto de vista ocidental e moderno" (ANGELOV, 2013, p. 6, tradução nossa). Assim, ele imputa uma imagem distorcida:

O bizantinismo, tal como o balcanismo, é um conceito de "alteridade" pelo qual Bizâncio é transformado num "outro" aleijado do constructo cultural da Europa. Como tal, o bizantinismo, tal como balcanismo, envolve a estereotipificação e categorização de um mundo que reside nas fronteiras do que o Ocidente vê como seu próprio território cultural. O bizantinismo, tal como o balcanismo, categoriza o "outro" como uma imagem imperfeita e incompleta do eu, encaixando-se assim no constructo cultural comum da civilização europeia como um tipo de autorreflexão caricaturado. Quanto a isso, os constructos bizantinistas diferem do orientalismo de Said, pois eles lidam com variações de um tipo único, mas não procuram diferenciar entre dois tipos diferentes (ANGELOV, 2013, p. 7, tradução nossa).

Entender as relações entre Bizâncio e o Ocidente vai além de simplesmente reconhecer o uso impróprio de títulos ou periodizações: estamos falando de um caso aberrante de imputação de uma essência carregada de preconceitos que são anteriores mesmo a literatura especializada. "Bizâncio, bem como o bizantinismo, são assim designações de dentro da semiosfera ocidental estabelecidas

\footnotetext{
${ }^{15}$ Para um apanhado enciclopédico dos estudos ocidentais sobre Bizâncio até o começo do século XIX, cf. VASILIEV, 1952, p. 3-42. Cf. também HAARER, 2010, e toda a Part IV: The World of Byzantine Studies em STEPHENSON, 2010b. Para percepções iluministas, românticas e pós-românticas, com foco especial nas percepções nacionalistas dos estados emergentes dos Balcãs, cf. MISHKOVA, 2015.

16 Para exemplos, cf. ANGELOV, 2003, p. 7-11; CAMERON, 2006, p. 3-5. Quanto aos dicionários, não precisamos ir longe, pois as entradas em nossos dicionários lusófonos repetem as mesmas definições. Por exemplo, o Novo Dicionário da Língua Portuguesa define bizantinice como "[...] 2. Asneira, tolice, bobagem" e bizantinismo como "[...] 2. Fig. Interesse por discussões frívolas ou insignificantes, sem resultado prático, como as questões tratadas pelos teólogos bizantinos; [...]" (HOLANDA, 1975, p. 209-210). O Dicionário Priberam da Língua Portuguesa coloca na entrada bizantino a seguinte definição: "[...] 2. [Figurado] Fútil, pretencioso [...]" (BIZANTINO, 2018). Para outros usos e apropriações de Bizâncio, cf. BODIN, 2016; STEPHENSON, 2010a.
} 


\section{artigos}

Identidade romana no Império Bizantino: novas perspectivas de um problema de alteridade

como uma realidade histórica, mas tomando características imaginárias" (BODIN, 2016, p. 17, tradução nossa). O escopo disso é surpreendente:

Como um discurso de "alteridade", o bizantinismo evolui e reflete sobre os piores sonhos e pesadelos do Ocidente sobre si mesmo. Assim, Bizâncio foi rebaixado em uma espécie de ramo inferior da árvore evolutiva da história, na qual o Ocidente - o Ocidente idealizado - nunca evoluiu, mas poderia. Durante o iluminismo, Bizâncio se tornou a encarnação da cultura e da política das quais o Ocidente queria libertar-se. Bizâncio representava também a união repulsiva do estado e da igreja, ou o domínio do primeiro sobre o último, ao qual o Ocidente não queria retornar. Durante o século $\mathrm{XIX}$, o bizantinismo se tornou o princípio ideológico do imperialismo e do absolutismo que o Ocidente, por enquanto, sacudira - ou ainda estava tentando sacudir - em troca do ideal do Estado-Nação liberal. Durante meados do século XX, o bizantinismo foi chamado a explicar a existência da ideologia comunista, uma espécie de renúncia ao fato de que Marx e Engels vieram realmente do Ocidente. Agora que o comunismo desapareceu, o bizantinismo como uma série de legados históricos de formação foi responsabilizado pelo terrível contraste entre a paz e a prosperidade no Ocidente e o desastre político e econômico na maioria dos Balcãs. E é improvável que este seja o último rosto do bizantinismo (ANGELOV, 2013, p. 14, tradução nossa).

À vista disso, podemos ter uma ideia do contexto político, cultural e intelectual que esteve por trás da historiografia ocidental no decorrer desse tempo. Sabemos que os bizantinos afirmavam que eram romanos, o que torna "Bizâncio" um conceito problemático, já que o "Império Bizantino" nunca existiu. Muitos passos importantes foram dados em direção a uma leitura mais crítica, e um dos aspectos mais fascinantes que foram estudados nos últimos tempos é como a identidade romana pode migrar para o mundo helênico e manter ao longo de toda a Idade Média sua coesão, embora seus novos detentores fossem consideravelmente diferentes daqueles que a originaram. 


\section{artigos}

Guilherme Welte Bernardo

\section{Os romanos da Nova Roma}

Como notado por T. L. W. Berkers, há quatro principais teorias sobre a identidade bizantina. A primeira teoria, mais antiga e notória entre historiadores gregos como Apostolos Vakalopoulos e Peter Charanis, enxerga Bizâncio como uma manifestação medieval da identidade nacional grega. Como o termo "heleno" ganhou uma conotação negativa relacionada ao paganismo, os gregos medievais teriam escondido sua identidade por baixo do rótulo romano. ${ }^{17} \mathrm{~A}$ segunda teoria, muito difundida, pode se dizer, por historiadores de origem eslava como Dimitri Obolensky e Cyril Mango, descreve Bizâncio como um império medieval multiétnico cujo principal elemento era a fé ortodoxa. ${ }^{18}$ Afastando-se dessas duas, a terceira teoria, proposta na última década por Anthony Kaldellis, busca restaurar a conexão entre Bizâncio e Roma. Para o autor, a romanidade era a identidade do Império, ou melhor, a identidade nacional de Bizâncio: Kaldellis propõe a ousada tese de que Bizâncio era uma espécie de estado-nação medieval dos romanos. ${ }^{19}$ A quarta e mais recente, proposta por Yannis Stouraitis, propõe uma abordagem etnocultural onde grupos étnicos são definidos por certos atributos, como um nome coletivo e um mito de origem comum. Para o autor, essas teorias anteriores falharam em reconhecer que as fontes disponíveis pertencem a uma elite letrada, sendo impossível tratar de forma geral sobre a identidade de todos os cidadãos (BERKERS, 2017, p. 4-6). ${ }^{20}$ A tese de Gill Page sobre as transformações da identidade bizantina entre 1200 e 1420 é também digna de nota. A autora entende essa identidade como romana e de caráter étnico, indo na contramão das outras teorias. ${ }^{21}$

Será discutida especialmente nesta parte do artigo a terceira teoria, sendo a quarta notada enquanto resposta à terceira. Como Anthony Kaldellis restaura o caráter romano dos bizantinos em

\footnotetext{
${ }^{17}$ Cf., por exemplo, VAKALOPOULOS, 1968; CHARANIS, 1972.

${ }^{18} \mathrm{Cf}$. , por exemplo, OBOLENSKY, 1971; MANGO, 2008.

${ }^{19}$ Cf. KALDELLIS, 2007, 2012, 2017.

${ }^{20}$ Cf. STOURAITIS, 2014, 2017.

${ }^{21}$ Cf. PAGE, 2008. A obra da autora é inovadora, dando voz a muitas fontes primárias. Anthony Kaldellis (2009), representante da terceira teoria, realizou uma resenha crítica da obra, dialogando com sua tese.
} 


\section{artigos}

Identidade romana no Império Bizantino: novas perspectivas de um problema de alteridade sua análise, dando ênfase ao processo de romanização que transformou gregos e outros em romanos, será impossível falar sobre identidade bizantina a partir de agora ignorando seus trabalhos. Além disso, sua tese nos ajuda a complementar o que já foi levantado neste artigo. Assim, será apresentada aqui uma breve introdução a suas obras sobre o tema, ressaltando também as críticas que elas vêm recebendo nos últimos anos.

Publicada em 2007, Hellenism in Byzantium: The Transformations of Greek Identity and the Reception of the Classical Tradition de Anthony Kaldellis é um dos mais proeminentes trabalhos lançados nos últimos anos sobre identidade bizantina com um forte caráter revisionista. Apesar de ser um trabalho mais amplo, cujo foco é o helenismo, o segundo capítulo ("The world a city": Romans of the East) apresenta um estudo inovador do processo de romanização do mundo grego, abordando os motivos que gradualmente limitaram o alcance da identidade helênica perante a ordem política romana e como esta foi convertida à língua grega na Antiguidade Tardia sem diminuir o poder coerente e normativo de sua identidade. Seu estudo se propôs a ser "[...] a primeira descrição moderna de Bizâncio como România" (KALDELLIS, 2007, p. 44, tradução nossa). Além disso, o capítulo apresenta uma tese polêmica sobre a disposição de Bizâncio como um "estado-nação medieval", rejeitando a tese de que Bizâncio seria um "império multiétnico" com uma ideologia ecumênica universal. ${ }^{22}$

Segundo Kaldellis, no começo do século IV, uma simbiose entre "Roma" (comunidade histórica e política) e "Grécia" (idioma e conhecimento) já estava em curso, e ao final da Antiguidade Tardia a romanização do Oriente grego estava completa com todos reconhecendo os direitos de Roma como uma comunidade política normativa. ${ }^{23}$ Sua obra propõe uma releitura das origens da integração dos gregos na sociedade romana e seus mecanismos de funcionamento e perpetuação, defendendo que o Oriente também passou por um processo de romanização, embora sem obliterar aspectos locais.

\footnotetext{
22 Para uma crítica a ideia de um império multiétnico, cf. também KALDELLIS, 2014, p. 137-139; CAMERON, 2014, p. 3840.

${ }^{23}$ Segundo Kaldellis (2007), esse processo limitou drasticamente o alcance do helenismo, que ficaria num limbo até ser revivido a partir do século $\mathrm{XI}$ em diferentes contextos, mas sem derrubar a identidade romana.
} 


\section{artigos}

Guilherme Welte Bernardo

A língua e os costumes gregos, especialmente a paideía, não foram abandonados, mesmo porque isso nunca fora exigido. Na prática, o grego era a língua administrativa do Oriente desde a República e era visto já nos tempos do imperador Cláudio (10 a.C.-54 d.C.) como uma língua romana ao lado do latim (KALDELLIS, 2007, p. 49, 54-55, 66-67). O processo de romanização permitiu que fosse criada uma ampla comunidade de "novos romanos", o que aos poucos fez com que Roma deixasse de ser em Roma. "Em muitos textos da antiguidade tardia - gregos e latinos, cristãos e pagãos - Roma é aclamada a patria comum de todos os povos. Roma foi A Cidade, uma cidade tornada um mundo" (KALDELLIS, 2007, p. 48, tradução nossa).

Kaldellis trabalha com a premissa de que os bizantinos eram de fato romanos, reforçando o argumento de que o Ocidente lhes negou essa nomenclatura por motivos políticos e identitários, algo enraizado pelos historiadores ocidentais e comprado pelo nacionalismo grego. Nesse sentido, Kaldellis retoma alguns argumentos de Bury de que a periodização arbitrária dificulta nosso entendimento sobre essa sociedade:

Ao fazê-lo, ambos os lados perpetuaram o viés medieval ocidental contra o império oriental, segundo o qual os bizantinos eram apenas gréculos, não verdadeiros romanos. Roma pertence ao Ocidente, é instintivamente assumido, e ao mundo de língua latina, e assim outras "essências" tiveram que ser imaginadas para Bizâncio, como, por exemplo, ortodoxia grega, ortodoxia ecumênica, despotismo oriental ou mesmo helenismo medieval. Para muitos historiadores ocidentais, Roma também pertence à Antiguidade e qualquer coisa mais tarde do que isso pode, na melhor das hipóteses, constituir uma "recepção", apesar do fato de que somente no caso de Bizâncio estamos lidando com uma continuidade política, social e cultural de Júlio César a Constantino XI Paleólogo. Mas a existência de um estado e comunidade política únicos com uma história contínua durante mais de dois mil anos derrota a especialização acadêmica. Periodização, nesse caso arbitrária, requer novos nomes tais como "Bizâncio", e novos nomes sugerem uma diferente "essência" (KALDELLIS, 2007, p. 43, tradução nossa). 


\section{artigos}

Identidade romana no Império Bizantino: novas perspectivas de um problema de alteridade

Além disso, a perspectiva de Kaldellis difere das demais por não definir a romanidade bizantina em termos religiosos nem por laços étnicos (no sentido de uma crença numa ascendência comum), mas sim por meio do que ele acredita ser um consenso social de pertencimento a uma única comunidade política histórica, definida por leis, instituições, religião, língua e costumes (KALDELLIS, 2007, p. 43-44). Rejeitando a interpretação que liga a concessão de cidadania a todos os homens e mulheres livres pelo imperador Caracala em 212 à persuasão de uma "obrigação cívica", o autor move o foco para aspectos mais sutis, como a forma como as pessoas se sentiam em relação ao Império:

A romanização esteve completa quando os povos anteriormente conquistados tomaram consciência de um "consenso em relação ao direito de Roma em manter a ordem social e estabelecer uma cultura política normativa". Até lá, a maioria dos súditos da România bizantina carecia da necessidade, do vocabulário e das categorias mentais para afirmar uma identidade que não estivesse integrada à ordem romana. Eles aceitaram a reivindicação transmitida por Roma que a autoridade era legítima somente quando servia o bem-estar dos provinciais. Foi, afinal, uma concepção expansiva e igualitária da comunidade romana e de Roma como pátria comum de todos os povos, conjugada talvez com o mito de Alexandre, o Grande, como apóstolo da fraternidade do homem, que inspirou o acima mencionado édito de Caracala, ele próprio o rebento de uma dinastia provincial. [...] Etnicidade era irrelevante já que a comunidade era agora definida por consenso, lei e costume. E como muitas fontes testificam, após 212 havia apenas uma lei em todo o império (KALDELLIS, 2007, p. 48, tradução nossa).

A crença nesse coletivo, segundo Kaldellis, não pode ser vista como uma mera ficção do sistema, pois era uma realidade constantemente promulgada por documentos oficiais que definiram, individualmente e coletivamente, identidades romanas. A influência na moral e na mentalidade dessas ficções de longa duração presentes em toda a história romana contribuiu para a manutenção da ordem social dos romanos. O Império foi criado pelas armas, mas era mantido por meio de um consenso, como qualquer estado-nação moderno, sem ignorar os mecanismos de controle social e 


\section{artigos}

Guilherme Welte Bernardo

manufatura do consentimento operativo presentes em ambos (KALDELLIS, 2007, p. 50-51). Segundo o autor:

Estes novos romanos, da Grã-Bretanha até a Arábia, acabaram por compartilhar o mesmo calendário, pesos e medidas, cunhagem, censo e impostos, monumentos públicos, rituais de fidelidade, festivais, jogos e culto imperial, acampamentos e exércitos, tribunais e leis, oportunidades sociais políticas, arquivos públicos, paideia e língua(s), todas as quais foram efetivamente implantados pelas autoridades, de modo a lembrar constantemente a população provincial de sua participação cada vez mais igual na politeia e provocar sua participação ativa. Crucialmente, os provincianos sabiam que eles todos pertenciam à mesma comunidade global precisamente pelo fato de que eles compartilhavam todas essas coisas. "Ralis, desfiles, festivais: todos visam consolidar a unidade simbólica de um povo e sua subserviência a um conjunto dominante de objetivos." Marcos ao longo de estradas padronizadas criavam uma vasta rede imaginária que ligava a periferia ao centro político e ideológico. O grau de uniformidade (e, portanto, previsibilidade) no trabalho era surpreendente: os mesmos festivais eram celebrados da fronteira do Eufrates à Grã-Bretanha; os campos militares eram construídos de acordo com as especificações com tamanha regularidade invariável que os portões eram construídos mesmo quando eles se abriram diretamente em ravinas íngremes. E, na antiguidade tardia, é até mesmo possível falar de uma organização "nacionalizada" de jogos e aclamações de circo, que promoviam a ideologia imperial e traziam cidadãos para as lealdades transívicas de todo o império, reforçando "a identificação com uma sociedade provincial e imperial mais ampla". Somente no final do século XIX ou início do século XX que as nações modernas alcançaram esse nível de uniformidade (KALDELLIS, 2007, p. 51, tradução nossa).

Assim, Kaldellis defende que a sociedade bizantina deve ser considerada como um estadonação pré-moderno onde a romanidade funcionava como uma espécie de identidade nacional. Embora isso possa causar certa estranheza num primeiro momento, é importante notar que o debate sobre a possibilidade de nações ou estados-nação anteriores à modernidade nunca foi fechado e 


\section{artigos}

Identidade romana no Império Bizantino: novas perspectivas de um problema de alteridade parece ter se reaquecido nos últimos anos. ${ }^{24}$ Assim, é preciso ter isso em mente antes de desconsiderá-la como um mero anacronismo, valendo antes uma melhor análise teórica e conceitual da proposta do autor. Recentemente Kaldellis fez uma apologia conceitual de sua tese, afirmando que:

Muitos bizantinistas, como muitos historiadores da pré-modernidade, negam axiomaticamente a existência de nações pré-modernas e estão comprometidos com o que é às vezes chamado de escola modernista da formação da nação, que foi pioneira nos anos 60, 70 e 80 por historiadores e antropólogos da modernidade tais como Ernest Gellner, Eric Hobsbawm, Benedict Anderson e outros, que viam os estados-nação exclusivamente no contexto de seu surgimento moderno. Stouraitis, por exemplo, refere-se a isso como "o axioma sociológico ainda válido e preponderante sobre a modernidade das nações e identidades nacionais". $\mathrm{Na}$ realidade, no entanto, este modelo é embaraçosamente desatualizado e sofre ataque de muitas direções, tanto empíricas (estudiosos estão aduzindo um número crescente de povos pré-modernos que correspondem definições de nação neutras de período) assim como teóricas (os modernistas confundem os processos específicos pelos quais algumas - não todas - nações modernas emergiram como definições trans-históricas da nacionalidade). A doutrina modernista foi até destronada da Very Short Introduction ao nacionalismo de Oxford (KALDELLIS, 2017, p. 200-201, tradução nossa).

É importante notar que esses estudos sobre nações pré-modernas não têm como objetivo destituir a modernidade de ser, de fato, a era das nações, dos estados nacionais e do nacionalismo (alguns consideram este um fenômeno exclusivamente moderno); antes, o que se busca é afirmar que é possível encontrar outros tipos de nações ou estados-nação em períodos pré-modernos. Kaldellis caminhou recentemente por esse mesmo caminho:

\footnotetext{
${ }^{24}$ Cf, por exemplo, DELANTY e KUMAR, 2006; GAT, 2013; GROSBY, 2005; ICHIJO e UZELAC, 2005; SCALES e ZIMMER, 2005.
} 


\section{artigos}

Guilherme Welte Bernardo

É suficiente para agora que Bizâncio seja reconhecido como algo parecido com um estado-nação porque isso por si só refuta a visão de que ele era totalmente diferente de um estado-nação. Estados-nação exigem, portanto, um sentido de comunidade política, "por mais tênue que seja", e "algumas instituições comuns e um único código de direitos e deveres de todos os membros da comunidade"; além disso, um território controlado por um estado e valorizado por associações religiosas ou históricas; e "uma medida de valores e tradições comuns entre a população ou, pelo menos, sua comunidade 'central'." Bizâncio cumpre facilmente esses requisitos, com sua única língua dominante, religião, aparelho estatal e cultura homogênea (KALDELLIS, 2012, p. 394, tradução nossa). ${ }^{25}$

Segundo o etnossimbolista Anthony D. Smith, o problema de se falar em nações pré-modernas reside numa questão conceitual do que significa uma nação ou um estado nacional. Nesse sentido, Smith propõe que seja buscada uma definição mais neutra desses conceitos, que o desatrelem da nação e dos estados-nação enquanto fenômenos modernos ligados a contextos específicos, que não serão necessariamente encontrados em outros períodos históricos. Smith, por exemplo, dá o seguinte tipo ideal de nação como geralmente anunciado:

(1) a nação é uma comunidade geograficamente limitada, com fronteiras reconhecidas, dentro das quais os membros residem, e com um claro centro de autoridade;

(2) a nação é uma comunidade legal, isto é, seus membros têm direitos e deveres comuns como membros sob um código único de lei; (3) como resultado, a nação é uma comunidade de participação em massa, com todas as classes participando na política e na sociedade; (4) a cultura da nação é igualmente uma cultura de massa e pública, com elementos culturalmente distintivos inculcados por meio de instituições educacionais em massa;

(6) a nação e seu estado fazem parte de um sistema internacional mais amplo de

${ }^{25}$ As citações entre aspas fazem referência a SMITH, 1991, p. 8-15. 


\section{artigos}

Identidade romana no Império Bizantino: novas perspectivas de um problema de alteridade

estados nacionais, dos quais são membros soberanos; (7) a nação é uma comunidade humana que deve sua concepção e legitimação ao nacionalismo, a ideologia (SMITH, 2005, p. 34-35, tradução nossa).

Segundo o autor, sociedades da Antiguidade como o Egito Antigo falham facilmente em cumprir os requisitos exigidos nessa definição. No entanto, se esse tipo ideal fosse redefinido com base em parâmetros desassociados da visão de mundo do nacionalismo, poderíamos ter uma alternativa que talvez consiga abranger uma sociedade como essa:

(1) a descoberta e a forjamento de uma autoimagem comum, incluindo um nome próprio coletivo, que simboliza "nós" em oposição aos outros que nos rodeiam; (2) o cultivo de memórias, mitos, símbolos e tradições distintas da comunidade de cultura histórica formada com base em uma ou mais categorias étnicas e comunidades;

(3) a ocupação, residência e desenvolvimento de uma pátria ancestral comum com fronteiras claras e reconhecidas; (4) a criação e difusão de uma cultura pública distintiva para os membros da coletividade;

(5) a observância de costumes comuns distintivos e o enquadramento de leis comuns para os membros (SMITH, 2005, p. 39, tradução nossa).

Esses pontos alavancados são somente um exemplo da possibilidade de se abrir conceitualmente o termo para algo mais neutro e menos ligado a mecanismos modernos. Para Smith, o conceito atual é fruto de uma ideologia (cívico-territorial) e de um meio (a Europa Ocidental dos séculos XVIII e XIX) e tem dificuldade de se encaixar em outros casos modernos de formação nacional, como o asiático e o islâmico, como apontado por outros especialistas (SMITH, 2005, p. 3637). ${ }^{26}$ Além disso,

O nacionalismo, como Walker Connor repetidamente declara, é um fenômeno de massa; ele apela "ao povo". Mas assim, ele continua, também é a nação. Se for esse

${ }^{26} \mathrm{O}$ autor faz referência a TØNNESSON e ANTLÖV, 1996; SULEIMAN, 2003. 


\section{artigos}

Guilherme Welte Bernardo

o caso, se não podemos falar de uma nação até que a grande maioria de sua população participe em sua vida política, o que nas democracias significa direito a voto, então não podemos realmente identificar nações até pelo menos depois da Primeira Guerra Mundial, porque as mulheres não foram emancipadas na Europa e na América até depois de 1918. Do que devemos chamar as sociedades desses estados antes dessa aurora libertadora? Devemos descartar suas autodenominações nacionais como uma simples retórica ilusória? As pessoas não podem sentir que pertencem a uma "nação" sem participar de sua vida política? E o que, nesse contexto, constitui uma grande maioria? Quais das muitas classes de cidadãos de segunda classe, estrangeiros naturalizados, refugiados e semelhantes? Devemos dizer que porque uma minoria significativa da população não recebe direitos de cidadania iguais, não podemos descrever essa comunidade em particular como uma nação? (SMITH, 2005, p. 37, tradução nossa).

O caso de Bizâncio é singular, pois existem elementos que podem nos soar familiares num primeiro momento, em especial porque a modernidade possui bases teóricas oriundas da herança romana, mesmo que revisadas e expandidas. Para Kaldellis, por exemplo, a ideia de "participação popular" existe em Bizâncio por meio de mecanismos próprios. ${ }^{27}$ Além disso, esses romanos podiam ver seus impostos sendo utilizadas para o bem-estar das províncias, em prédios de utilidade pública e instituições de caridade; o dinheiro servia até mesmo para subsídios de projetos locais, auxíliodesastre, compensação para cidadãos capturados pelos bárbaros etc. Isso representa uma das características da noção de "[...] koinon, o 'compartilhamento' da politeia [...]" (KALDELLIS, 2007, p. 50, tradução nossa), o que alimentava a ideia de uma mesma comunidade global, uma unidade fraternal de pessoas, somada a um estado cuja ideologia estava enraizada na ideia de servir a um interesse comum de todos os cidadãos. O próprio imperador é entendido como subordinado à política que ele governa. ${ }^{28}$

\footnotetext{
27 Para alguns paralelos com o pensamento moderno, cf. KALDELLIS, 2015b, p. 96-117.

${ }^{28}$ Segundo o autor, o imperador realizava um juramento de ofício como todos os outros. Para os romanos, um rei deveria ser rei de algo, de um "[...] corpo corporativo que habilitava magistrados para agir com autoridade, nesse caso a res publica. Em teoria, um imperador poderia ser e às vezes era deposto por falhar com seus deveres em relação aos seus
} 


\section{artigos}

Identidade romana no Império Bizantino: novas perspectivas de um problema de alteridade

Essa noção de politeía é trabalhada melhor por Kaldellis em The Byzantine Republic: People and Power in New Rome, publicada em 2015. Essa é uma obra tão ou mais provocante quanto a anterior, retomando algumas propostas de Hans Georg Beck. ${ }^{29}$ Segundo Kaldellis, a partir do século IV, o termo grego politeía foi usado para traduzir o latino res publica. O termo perde completamente o sentido que possuía na antiguidade grega, sendo totalmente colonizado por Roma (KALDELLIS, 2015b, p. 20). Para os romanos e os bizantinos, essa "república" não era entendida como uma fase da história romana como a periodização moderna induz, mas como um tipo de sociedade que ao longo do tempo foi governada por diferentes regimes. As fontes bizantinas evidenciam que os escritores do período intermediário viram a politeía dos romanos se alongando do tempo da monarquia até os imperadores bizantinos. A "República" é referida como o governo dos cônsules (KALDELLIS, 2015b, p. 29).

Esse trabalho é sem dúvidas importante por buscar entender as dinâmicas internas daquela identidade, tendo como objetivo "[...] reabilitar a dimensão romana de Bizâncio e a identidade romana dos próprios bizantinos" por meio da apresentação de "[...] um argumento original em relação à natureza do que chamamos de 'Império Bizantino' como uma sociedade política" (KALDELLIS, 2015b, p. ix, tradução nossa). Os capítulos III e IV tentam demonstrar como a "soberania popular" funcionava em teoria e na prática na politeía, e Kaldellis oferece um grande leque de exemplos realmente impressionantes, valendo a pena ressaltar aqui um deles:

Em 532, o povo da Cidade tentou derrubar o regime do imperador Justiniano em uma das revoltas mais violentas da história romana, a revolta de Nica. Ela foi, sem dúvidas, provocada por um confronto entre as facções e as autoridades urbanas, mas logo adquiriu um caráter geral à medida que a população tomou parte com suas queixas contra o regime, incendiando o praitorion (o que se espalhou rapidamente). Deve-se notar que, eventualmente, a maioria ou todo o senado se juntou ao levante, mas não o orquestrara, e os imperadores rivais proclamados pela multidão,

súditos" (KALDELLIS, 2007, p. 49, tradução nossa).

${ }^{29}$ Cf. BECK, 1970, 1978. 


\section{artigos}

Guilherme Welte Bernardo

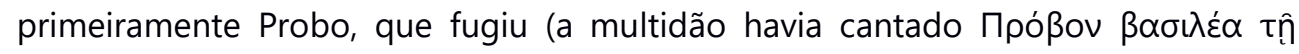

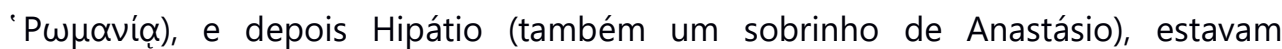
indispostos, embora Hipátio houvesse começado a se animar. Foram as pessoas, por iniciativa própria, que o proclamaram imperador no hipódromo, o que indica que elas acreditavam que tinham o direito de fazer isso. Nenhuma fonte contesta essa crença. Justiniano fez concessões para pacificar a multidão, destituindo oficiais impopulares cuja deposição fora exigida e aparecendo no hipódromo para negociar com a população. Quando tudo parecia perdido, ele considerou escapar, até que, de acordo com Procópio, foi encorajado por sua esposa Teodora, a quem o historiador geralmente apresenta como uma inimiga dos modos e ordens da politeia romana livre. De qualquer forma, essa foi a única insurreição popular na história bizantina que falhou (KALDELLIS, 2015b, p. 121, tradução nossa).

Kaldellis acredita que é a crença na legitimação popular do imperador (o que incluía igualmente certa forma de legitimação pelo Senado, Exército e mesmo a Igreja) que sustenta o mecanismo do poder imperial. Em sua aclamação, os imperadores eram geralmente recebidos com gritos de Áxios! ("Digno!") pela multidão, mas caso esta gritasse Anáxios ("Indigno!") era um sinal de futuras dores de cabeça, pois "[...] dava legitimação à revolução e apontava a suspensão da ordem legal" (KALDELLIS, 2015b, p. 164, tradução nossa). Assim, o jogo político envolvia a noção de popularidade dos imperadores e de "opinião pública" (KALDELLIS, 2015b, p. 125). ${ }^{30} \mathrm{O}$ autor compreende que as recorrentes guerras civis bizantinas são como uma forma de "eleição" onde potenciais líderes competiam pelo favor da população. "Esta interpretação da guerra civil bizantina explica o seguinte fato notável: nenhum estado na história jamais teve mais guerras civis que não mudaram em nada a estrutura ou a ideologia da política" (KALDELLIS, 2015b, p. 138, tradução nossa).

\footnotetext{
30 Para esse tipo de manifestação além da capital, cf. KALDELLIS, 2015b, p. 150-159.
} 


\section{artigos}

Identidade romana no Império Bizantino: novas perspectivas de um problema de alteridade

Kaldellis também busca por meio desse enfoque na politeía destronar o velho modelo que interpreta Bizâncio pelo viés puramente "teocrático". ${ }^{31}$ Aqui sua motivação é a mesma: restaurar o lugar da romanidade na análise da sociedade bizantina. Segundo o autor,

A palavra "teocracia" é muito lançada para lá e para cá no campo, assim como "absolutismo" e similares (o debate agora é entre usar "teocrático" ou "teocêntrico"). Quando o imperador bizantino é introduzido e definido na maioria dos livros e artigos, é, em primeiro lugar e muitas vezes exclusivamente, em relação a Deus, não a politeia que ele governava. Em muitos estudos, a politeia está completamente ausente, não apenas como um conceito, mas como um elemento crucial da ontologia política bizantina. Então, quando estabelecemos a "ideia", cujos elementos são extraídos de um conjunto particular de textos (sobretudo panegíricos e algumas fantasias apocalípticas), ao lado do modelo de política bizantina que eu apresentei nos capítulos anteriores, encontramos uma lacuna quase intransponível. A república monárquica romana não pode ter sido a mesma teocracia imperial ortodoxa. As duas não podem se referir à mesma sociedade - e ainda assim se referem (KALDELLIS, 2015b, p. 166, tradução nossa).

Para Kaldellis, a chamada "ideia imperial" (a visão teocrática de Bizâncio) é uma interpretação teológica ex post facto. Ela surge depois da res publica e assim estava em constante contradição com a mesma. Ela "[...] foi uma tentativa da corte de melhorar retoricamente a posição vulnerável na qual ela se encontrava ao gerir uma república turbulenta" (KALDELLIS, 2015b, p. xiii, tradução nossa). Há, assim, uma profunda contradição entre a visão sacra e intocável do imperador e os constantes motins para derrubar imperadores impopulares. 32 "Precisamos da república para explicar o que o povo estava fazendo, porque a 'ideia imperial' não explica" (KALDELLIS, 2015b, p. 171, tradução nossa).

\footnotetext{
${ }^{31}$ Cf., por exemplo, RUNCIMAN, 1978.

${ }^{32}$ Além disso, Kaldellis aponta que os imperadores que levaram a ideia imperial ao limite foram alvo de chacota por historiadores. Miguel Pselo, por exemplo, "[...] zombou de Romano III por acreditar que, como Deus lhe dera o trono, ele o apoiaria em seus diversos esforços, militares e dinásticos. Pselo também tentou recobrar a razão de Constantino IX, que concluiu que como ele era protegido por Deus, não precisava de guardas (isso levou a atentados contra sua vida). Esses
} 


\section{artigos}

Guilherme Welte Bernardo

Kaldellis tenta fechar essa lacuna da seguinte forma: a maioria dos bizantinos acreditavam, embora em contextos diferentes, em ambos os conjuntos de crença, mesmo que não pareçam estar em comunicação um com o outro. Desse modo, o imperador era apontado por Deus, mas se ele fosse um "tirano" indigno do seu cargo na politeía, os cidadãos acreditavam ter todo o direito de depô-lo. A crença em coisas contraditórias como essas se dá quando cada uma delas é vantajosa em determinado contexto. Isso não é exclusivo dos bizantinos, nem sequer é um caso isolado. Uma lógica situacional parecida é utilizada pelo patriarca Fócio (séc. IX): dependendo do contexto, os bárbaros poderiam ser descritos como pagãos selvagens ou nobres figuras dignas de imitação. Como mostra Kaldellis, o mesmo Fócio, aliás, apresenta num tratado em forma de carta uma visão radicalmente secular quanto a origem dos estados (KALDELLIS, 2015b, p. 182-184).

As teses de Bizâncio como um estado-nação medieval e o lugar do povo na politeía bizantina foram relativamente bem recebidas, influenciando outros pesquisadores, ${ }^{33}$ mas não foram isentas de críticas. Até o momento, as críticas mais substanciais foram tecidas por Yannis Stouraitis e John Haldon, que trataram, respectivamente, das duas obras trabalhadas acima, Hellenism in Byzantium e The Byzantine Republic.

Publicado em 2014, Roman identity in Byzantium: a critical approach é um longo artigo em resposta à tese de Kaldellis. Yannis Stouraitis considera que as fontes utilizadas foram essencialmente escritas pela elite letrada e possuem um discurso homogeneizante, não sendo possível concluir que as massas analfabetas e provinciais possuíam a mesma visão quanto a elas mesmas. Essa crítica é, na verdade, muito similar a outras sobre a potencial existência de nações pré-modernas: enquanto talvez seja possível identificar ideias nacionais em alguns textos, não é possível, por falta mesmo de evidências, descobrir como as massas populares se identificavam. ${ }^{34} \mathrm{O}$ autor também apresenta uma

imperadores são apresentados como delirantes, mas também é possível dizer que eles estavam apenas levando a ideia imperial a sua conclusão lógica, isto é, ao ponto de 'crença' real" (KALDELLIS, 2015b, p. 171, tradução nossa).

${ }^{33}$ Cf., por exemplo, BERKERS, 2017; FERNANDES, 2016; OLSON, 2011; ST-PIERRE, 2017.

${ }^{34}$ Cf., por exemplo, BREULLY, 2005, p. 84. 


\section{artigos}

Identidade romana no Império Bizantino: novas perspectivas de um problema de alteridade

tese alternativa, rejeitando tanto o modelo multiétnico quanto o de estado-nação. Para Stouraitis, é importante considerar que ser romano pode ter tido pesos diferentes entre os diversos grupos e nas diversas regiões do Império. Embora a elite letrada compartilhasse de uma noção de identidade romana, esta se dava em termos de aliança com a hierarquia constantinopolitana e sua cultura política:

Dentro desse quadro, a integração das elites étnicas à classe dominante romana representa o fator crucial que os impediu de instrumentalizar ideologias étnicas e lealdades regionais para promover políticas de separatismo político. No entanto, isso dificilmente impediu a diversidade etnocultural de permanecer um discurso social saliente dentro do império, como demonstra o uso sistemático de etnônimos nas fontes. A categorização etnocultural das populações provinciais mediante etnônimos certamente não representa a evidência de autoidentificação étnica em massa das pessoas comuns de forma subjetiva. No que diz respeito às massas analfabetas ou semianalfabetas, a autoidentificação deve ter se referido primariamente às microculturas regionais, enquanto que as noções de pertencimento a uma coletividade mais ampla de marcadores culturais compartilhados podem ter definido, apenas secundariamente, a identidade de segmentos das populações provinciais (STOURAITIS, 2014, p. 182, tradução nossa).

John Haldon elogiou as intervenções feitas por Kaldellis, mas ofereceu críticas pontuais ao modelo "republicano" proposto. No artigo "Res publica Byzantina? State formation and issues of identity in medieval east Rome" de 2016, o autor coloca em questão se o "povo" intervindo autonomamente na política refletia uma plena consciência das ideias republicanas em todos os envolvidos ou somente numa fina camada letrada da elite; além disso, o autor aponta que os interesses de um emaranhado de grupos são submersos numa consciência republicana, perdendose assim as motivações por trás de cada exemplo específico de oposição (HALDON, 2016, p. 8). Haldon também discute a problemática em torno dos conceitos de "ideologia" e "estado" (HALDON, 2016, p. 9-15) e critica a marginalização da análise socioeconômica na obra de Anthony Kaldellis (HALDON, p. 15-16). Sua conclusão é que 


\section{artigos}

Guilherme Welte Bernardo

Como uma demonstração de como conjuntos de ideias e conceitos continuaram a desempenhar um papel fundamental na autoidentidade da elite; de como as práticas e pressupostos político-culturais preexistentes (romanos, "republicanos") criaram o espaço metafórico dentro do qual as ideias sobre rebeliões legitimadas poderiam ser mantidas e colocadas em prática; como uma demonstração de como tais ideias poderiam impactar as atividades políticas da elite e, por vezes, outros grupos que poderiam pertencer ao "povo"; e como uma demonstração da inadequação das noções até então dominantes de uma "ideologia imperial" difusa, o argumento da república bizantina é persuasivo. Mas conflitos ou tensões socioeconômicos, competição por controle e acesso a recursos (seja em relação a dinheiro, mão-deobra, terra ou influência política ou ideológica - incluindo religiosa) são deixados de lado. No final, a ideia de que "o povo romano" era o árbitro definitivo de quem governava e de como se governava não é, para mim, convincente (HALDON, 2016, p. 15-16, tradução nossa).

Até o momento, Anthony Kaldellis fez duas principais apologias e atualizações da sua tese. Publicado em 2012 numa obra colaborativa, From Rome to New Rome, from Empire to Nation-State: Reopening the Question of Byzantium's Roman Identity retoma a discussão sobre Bizâncio como um estado-nação medieval e oferece alguns esclarecimentos conceituais. O artigo The Social Scope of Roman Identity in Byzantium: An Evidence-Based Approach, de 2017, é uma resposta direta à crítica de Stouraitis. Kaldellis buscou examinar uma gama maior de fontes de diferentes naturezas para reforçar sua tese. Além disso, o autor preferiu falar agora de uma "[...] ampla comunidade romana definida por critérios étnicos [...]" (KALDELLIS, 2017, p. 174, tradução nossa). Assim, ele realiza uma redefinição ou atualização teórica e conceitual de sua tese, embora não ataque sua antiga definição:

Para argumentar que a identidade romana em Bizâncio era nacional e não étnica, eu, em publicações anteriores, dependi de um modelo específico de etnia que está lentamente perdendo terreno entre os estudiosos. [...] Mas, embora muitos estudiosos ainda tenham essa definição de etnia, a maioria parece ter se deslocado para uma mais flexível, segundo o qual um grupo étnico pode ser identificado também com base em seu nome comum (ou etnônimo), cultura compartilhada, 


\section{artigos}

Identidade romana no Império Bizantino: novas perspectivas de um problema de alteridade

língua comum e religião, pátria, consciência de sua diferença em relação aos grupos vizinhos (por exemplos, romanos vs. búlgaros ou bárbaros em geral), instituições políticas comuns, sensação de ter uma história comum, parentesco percebido além da família ou qualquer combinação parcial, mas significante desses fatores. Nenhuma definição rígida cobrirá todos os grupos étnicos na história: alguns fatores serão inevitavelmente mais importantes para um grupo do que para outros. Em muitos contextos históricos, essa definição torna a etnicidade e a identidade nacional quase equivalentes e, de fato, alguns teóricos não acreditam que haja sempre muita diferença entre as duas (KALDELLIS, 2017, p. 175, tradução nossa).

Além da análise de outras fontes, Kaldellis afirma que a definição de elites empregada por Stouraitis é imprecisa e que é impossível tratar grupos tão díspares de modo homogêneo. Como exemplo, o autor questiona: "Os generais analfabetos tinham a mesma visão da identidade romana que os historiadores classicistas com muito menos poder social? De onde conseguiram essa visão?" (KALDELLIS, 2017, p. 177, tradução nossa). Kaldellis também afirma que muitos membros da elite da capital vieram das províncias e que a maioria da população provincial é descrita como romana em suas fontes. A única explicação viável para o autor é que eles cresceram expostos a essa noção; ou seja, eles não "aprenderam" a ser romanos em Constantinopla (KALDELLIS, 2017, p. 186). O autor também considera que afirmar que "[...] o exército, recrutado e acampado nas províncias, tinha uma identidade romana, mas que as comunidades das quais eles são oriundos e as quais prometeu defender não tinham [...]" seria uma acrobacia conceitual problemática (KALDELLIS, 2017, p. 189, tradução nossa). A conclusão do autor é que "A elite em Constantinopla se identificava como romana porque isso era extraído dessa comunidade horizontal estendida" (KALDELLIS, 2017, p. 207, tradução nossa).

\section{Conclusão}

Como demonstrado neste artigo, é preciso que os historiadores reflitam constantemente sobre a forma como se posicionam em relação ao seu objeto de estudo, pois isso afeta diretamente os resultados obtidos. Longe de se pregar um "objetivismo", o que se aponta é que a imposição de convenções, periodizações, essências ou mesmo critérios pessoais têm influenciado há muito tempo 


\section{artigos}

Guilherme Welte Bernardo

a forma como o "Império Bizantino", como convencionamos a chamar o Império Romano Medieval, é visto. O contexto intelectual ocidental também contribuiu para isso, tornando Bizâncio um caso paradigmático do que poderíamos chamar de dissimulação cultural. ${ }^{35}$ Como lembra Anthony Kaldellis, "Esses chamados bizantinos sabiam exatamente quem eram (romanos) e do que queriam ser chamados, mas são o povo medieval cujo nome os historiadores modernos se recusam a usar" (KALDELLIS, 2014, p. 107, tradução nossa). Algumas questões devem ser assim levantadas para reflexão. Ainda é possível dizer que Bizâncio é algo "totalmente distinto" de Roma? Deve-se ignorar o que os bizantinos diziam de si próprios? Caso a resposta seja positiva, é preciso refletir em que exatamente se vale tais posições e o papel do historiador frente ao seu objeto. $\mathrm{O}$ historiador deve tomar para si a função de impor um termo ou uma identidade a uma civilização do passado?

Infelizmente, somente uma muito breve discussão sobre esses temas pode ser aqui trabalhada, sendo deixados de lado muitos outros elementos devido ao espaço e a delimitação temática deste artigo. Espera-se, no entanto, que por meio desta muito breve revisão bibliográfica seja chamada a atenção para uma discussão importante que acontece atualmente sobre esses temas que recebe muito pouca atenção no Brasil. A ideia é que ele possa incentivar outras pessoas a se interessarem por essa única, curiosa e complexa sociedade medieval, da qual ainda há muito para ser explorado em nosso meio acadêmico.

Internacionalmente, nota-se que embora todos esses e outros estudos sobre diversas áreas dos Estudos Bizantinos estejam sendo produzidos, muito pouco parece alcançar trabalhos não especializados ou mesmo outros historiadores. Dimitris Krallis chamou recentemente a atenção a esse problema e urgiu por um corretivo "[...] se Bizâncio e os Estudos Bizantinos manterão uma

\footnotetext{
35 É possível fazer um paralelo com o conceito como formulado por Christopher J. Frey (2007). O autor propõe o termo dissimulação cultural como oposto a assimilação cultural para explicar como o clã Matsumae inventou e fortaleceu diferenças linguísticas e culturais entre japoneses e ainus para manter seu monopólio comercial. Apesar do contexto distinto, é possível propor a seguinte leitura quanto ao caso aqui estudado: que a intelectualidade ocidental fortaleceu diferenças em determinados momentos a partir do século IX com o objetivo de se afirmar como a única verdadeira herdeira intelectual, cultural e política de Roma.
} 


\section{artigos}

Identidade romana no Império Bizantino: novas perspectivas de um problema de alteridade

presença coerente nas imaginações dos jovens estudantes, dos futuros estudiosos e do público em geral" (KRALLIS, 2013, p. 197, tradução nossa).

\section{Referências bibliográficas}

ANGELOV, D. G. Byzantinism: The Imaginary and Real Heritage of Byzantium in Southeastern Europe. In: KERIDIS, D.; ELIAS-BURSAĆ, E.; YATROMANOLAKIS, N. (Ed.). New approaches to Balkan studies. Dulles: Brassey's, 2003. p. 3-23.

BALARD, M. Bizâncio visto do Ocidente. In: LE GOFF, J.; SCHMITT, J.-C. (Coord.). Dicionário Temático do Ocidente Medieval. Bauru, São Paulo: EDUSC, 2006. v. 1, p. 129-138.

BARBERO, A. Charlemagne: The Father of a Continent. Berkeley: University of California Press, 2014.

BECK, H.-G. Das Byzantinische Jahrtausend. München: C. H. Beck, 1978.

Res Public Romana: Vom Saatsdenken der Byzantiner. München: Verlag der Bayerischen Akademie der Wissenschaften, 1970.

BERKERS., T. L. W. Spectacle, Power \& Romanness in Byzantium: The Use of Roman Heritage in the Ceremonial Practices in the Hippodrome (10th-century). 2017. 60 f. Thesis (Master Geschiedenis) Faculteit Der Letteren, Radboud University Nijmegen, Nijmegen. Disponível em: <https://theses.ubn.ru.nl/handle/123456789/4548>. Acesso em: 15 out. 2018.

BESSERMAN, L. (Ed.). The Challenge of Periodization: Old Paradigms and New Perspectives. In: The Challenge of Periodization: Old Paradigms and New Perspectives. New York: Garland Publishing, 1996.

BIZANTINO. Dicionário Priberam da Língua Portuguesa, 18 out. 2018. Disponível em: <https://dicionario.priberam.org/bizantino>. Acesso em: 18 out. 2018.

BODIN, H. Whose Byzantinism - Ours or Theirs? On the Issue of Byzantinism from a Cultural Semiotic Perspective. In: MARCINIAK, P.; SMYTHE, D. C. (Ed.). The Reception of Byzantium in European Culture since 1500. Abingdon: Routledge, 2016. p. 11-42. 


\section{artigos}

Guilherme Welte Bernardo

BREUILLY, J. Changes in the political uses of the nation: continuity or discontinuity? In: SCALES, L.; ZIMMER, O. (Ed.) Power and the Nation in European History. Cambridge: Cambridge University Press, 2005. p. 67-101.

BROWN, P. The World of Late Antiquity: AD 150-750. New York: W. W. Norton, 1989.

CAMERON, A. Byzantine Matters. Princeton: Princeton University Press, 2014.

Procopius and the Sixth Century. London: Duckworth, 1985.

The Byzantines. Oxford: Blackwell Publishing, 2006.

The Mediterranean World in Late Antiquity: AD 395-700. 2a ed. Abingdon: Routledge, 2012.

CERTEAU, M. de. A Escrita da História. $2^{\text {a }}$ ed. Rio de Janeiro: Forense Universitária, 2008.

CHARANIS, P. How Greek was the Byzantine Empire? In: (Ed.). Studies on the Demography of the Byzantine Empire. London: Variorum Reprints, 1972.

CREMONA, L of. The Complete Works of Liudprand of Cremona. Washington, D.C.: The Catholic University of America Press, 2007. Tradução de: Paolo Squatriti.

DELANTY, G.; KUMAR, K. (Ed.). The SAGE Handbook of Nations and Nationalism. London: Sage Publications Ldt, 2006.

FERNANDES, C. C. A Crise Iconoclasta no Império Bizantino e a Defesa das Imagens em São João Damasceno: Um Debate sobre Autoridade Política. 2016. 138 f. Dissertação (Mestrado em História) Instituto de Ciências Humanas e Sociais, Universidade Federal de Ouro Preto, Mariana. Disponível em: <http://www.repositorio.ufop.br/handle/123456789/6580>. Acesso em: 15 out. 2018.

FÖGEN, M. T. Reanimation of the Roman Law in the Ninth Century: Remarks on Reasons and Results. In: SPRING SYMPOSIUM OF BYZANTINE STUDIES, 30., 1996, Birmingham. Papers... Abingdon: Routledge, 2016. p. 11-22. 


\section{artigos}

Identidade romana no Império Bizantino: novas perspectivas de um problema de alteridade

FREY, C. J. Ainu schools and education policy in nineteenth-century Hokkaido, Japan. Ann Arbor: ProQuest Dissertations Publishing, 2007.

GAT, A. Nations: The Long History and Deep Roots of Political Ethnicity and Nationalism. Cambridge: Cambridge University Press, 2013.

GRIG, L.; KELLY, G. Introduction: From Rome to Constantinople. In: (Ed.). Two Romes:

Rome and Constantinople in late Antiquity. New York: Oxford University Press, 2012. p. 3-30.

GROSBY, S. Nationalism: A Very Short Introduction. Oxford: Oxford University Press, 2005.

HAARER, F. K. Writing Histories of Byzantium: The Historiography of Byzantine History. In: JAMES, L. (Ed.) A Companion to Byzantium. Malden, MA: Blackwell, 2010.

HALDON, J. Byzantium in the Seventh Century: The Transformation of a Culture. Cambridge: Cambridge University Press, 1990.

Res publica Byzantina? State formation and issues of identity in medieval east Rome. Byzantine and Modern Greek Studies, [s.I.], v. 40, n. 01, p. 4-16, abr. 2016. Disponível em: <https://www.cambridge.org/core/journals/byzantine-and-modern-greek-studies/article/respublica-byzantina-state-formation-and-issues-of-identity-in-medieval-eastrome/6D2221DA98DF30DD99C5F51E814C4777>. Acesso em: 20 set. 2018.

HOLANDA, A. B. de. Novo Dicionário da Língua Portuguesa. Rio de Janeiro: Nova Fronteira, 1975.

ICHIJO, A.; UZELAC, G. (Ed.). When is the Nation?: Towards an Understanding of Theories of Nationalism. Abindgon: Routledge, 2005.

KALDELLIS, A. 09.04.10, Page, Being Byzantine. The Medieval Review, [Bloomington, IN], 2009. Publicação online sem paginação. Disponível em: <https://scholarworks.iu.edu/journals/index.php/tmr/article/view/16788>. Acesso em: 09 set. 2017. Ethnography after Antiquity. Foreign Lands and Peoples in Byzantine Literature. Philadelphia, PA: University of Pennsylvania Press, 2013. 


\section{artigos}

Guilherme Welte Bernardo

. From Rome to New Rome, from Empire to Nation-State: Reopening the Question of Byzantium's Roman Identity. In: GRIG, L.; KELLY, G. (Ed.). Two Romes: Rome and Constantinople in late Antiquity. New York: Oxford University Press, 2012. p. 387-404.

Hellenism in Byzantium: The Transformations of Greek Identity and the Reception of the Classical Tradition. Cambridge: Cambridge University Press, 2007.

OSU professor: The Byzantines were Romans. 2015a. Entrevista concedida a Tom Jackson. Disponível em: <http://www.sanduskyregister.com/story/201502180047>. Acesso em: 18 jun. 2018. . The Byzantine Republic: People and Power in New Rome. Boston: Harvard University Press, 2015b.

The Social Scope of Roman Identity in Byzantium: An Evidence-Based Approach. Byzantina Symmeikta, Athens, v. 27, p. 173-210, 2017. Disponível em: <https://ejournals.epublishing.ekt.gr/index.php/bz/article/view/10476>. Acesso em: 01 nov. 2017.

KRALLIS, D. The Outsider's Gaze: Reflections on Recent Non-byzantinist Readings of Byzantine History and on their Implications for our Field. Byzantina Symmeikta, Athens, vol. 23, p. 183-199, 2013. Disponível em: <https://ejournals.epublishing.ekt.gr/index.php/bz/article/view/3812>. Acesso em: 06 mar. 2016.

LAFFERTY, S. D. W. Law and Society in the Age of Theoderic the Great: A Study of the Edictum Theoderici. Cambridge: Cambridge University Press, 2013.

LAMERS, H. Greece Reinvented: Transformations of Byzantine Hellenism in Renaissance Italy. Leiden: BRILL, 2015.

LE GOFF, J. A História deve ser dividida em pedaços? São Paulo: Editora UNESP, 2015.

LEE, A. D. From Rome to Byzantium AD 363 to 565: The Transformation of Ancient Rome. Edinburgh: Edinburgh University Press, 2013. 


\section{artigos}

Identidade romana no Império Bizantino: novas perspectivas de um problema de alteridade

LOUTH, A. The eastern empire in the sixth century. In: FOURACRE, P. (Ed.). The New Cambridge Medieval History. Cambridge: Cambridge University Press, 2005. v. 1, p. 93-117.

MANGO, C. Bizâncio: O Império da Nova Roma. Lisboa: Edições 70, 2008.

MISHKOVA, D. The Afterlife of a Commonwealth: Narratives of Byzantium in the National Historiographies of Greece, Bulgaria, Serbia and Romania. In: DASKALOV, R.; VEZENKOV, A. (Ed.). Entangled Histories of the Balkans. Leiden: BRILL, 2015. v. 3, p. 118-270.

MOMIgLIANO, A. La caduta senza rumore di un impero nel 476 d.C. Annali della Scuola Normale Superiore di Pisa, [S.I.], v. 3, n. 2, p. 397-418, 1973. Serie III. Disponível em: <https://www.jstor.org/stable/24300634>. Acesso em: 25 set. 2017.

MOORHEAD, J. The Byzantines in the West in the sixth century. In: FOURACRE, P. (Ed.). The New Cambridge Medieval History. Cambridge: Cambridge University Press, 2005. v. 1, p. 118-139.

The Roman Empire divided, 400-700. 2. ed. Abingdon: Routledge, 2013.

NICOL, D. M. Byzantium and Venice: A Study in Diplomatic and Cultural Relations. Cambridge: Cambridge University Press, 1992.

The Byzantine View of Western Europe. Greek, Roman and Byzantine Studies, Durham, NC, v.

8, n. 4, p. 315-339, 1967. Disponível em: <http://grbs.library.duke.edu/article/view/11101>. Acesso em: 15 fev. 2017.

OBOLENSKY, D. The Byzantine Commonwealth: Eastern Europe, 500-1453. London: Weidenfeld \& Nicholson Ltd, 1971.

OLSON, A. K. "Part of our commonwealth": A study of the Normans in eleventh-century Byzantine historiography. 2011. 108 f. Thesis (Master of Arts) - Faculty of Arts and Social Sciences, Simon Fraser University, Vancouver. Disponível em: <http://summit.sfu.ca/item/11610>. Acesso em: 15 out. 2018.

PAGE, G. Being Byzantine: Greek Identity Before the Ottomans. Cambridge: Cambridge University Press, 2008. 


\section{artigos}

Guilherme Welte Bernardo

REINSCH, D. R. Hieronymus Wolf as Editor and Translator of Byzantine Texts. In: MARCINIAK, P.; SMYTHE, D. C. (Ed.). The Reception of Byzantium in European Culture since 1500. Abingdon: Routledge, 2016. p. 43-53.

RICHÉ, P. The Carolingians: A Family Who Forged Europe. Philadelphia, TN: University of Pennsylvania Press, 1993.

RUNCIMAN, S. A Teocracia Bizantina. Rio de Janeiro: Zahar Editores, 1978.

Gibbon and Byzantium. Daedalus, [S. I.], v. 105, n. 3, p. 103-110, summer 1976. Disponível em: <http://www.jstor.org/stable/20024419>. Acesso em: 03 fev. 2017.

SANDBERG, K. The so-called division of the Roman Empire in AD 395: Notes on a persistent theme in Modern historiography. Arctos, [S.I], v. 42, p. 199-213, 2008.

SCALES, L.; ZIMMER, O. (Ed.) Power and the Nation in European History. Cambridge: Cambridge University Press, 2005.

SIECIENSKI, A. E. The Papacy and the Orthodox: Sources and History of a Debate. Oxford: Oxford University Press, 2017.

SMITH, A. D. National Identity. Reno, NV: University of Nevada Press, 1991.

Were there nations in Antiquity? In: SCALES, L.; ZIMMER, O. (Ed.) Power and the Nation in European History. Cambridge: Cambridge University Press, 2005. p. 33-53.

SPIESER, J.-M. Du Cange and Byzantium. In: SPRING SYMPOSIUM OF BYZANTINE STUDIES, 29., 1995, London. Papers... Aldershot: Ashgate, 2000, p. 199-210.

STATHAKOPOULOS, D. A Short History of the Byzantine Empire. London: I.B.Tauris, 2014.

STEPHENSON, P. Byzantium's European Future. In: The Byzantine World. Abingdon: Routledge, 2010a. p. 505-509.

The Byzantine World. Abingdon: Routledge, 2010b. 


\section{artigos}

Identidade romana no Império Bizantino: novas perspectivas de um problema de alteridade

STOURAITIS, Y. Reinventing Roman Ethnicity in High and Late Medieval Byzantium. Medieval Worlds, Vienna, v. 5, p. 70-94, 2017. Disponível em: <http://www.medievalworlds.net/?arp=0x00369e4b>. Acesso em: 12 dez. 2017.

Roman identity in Byzantium: a critical approach. Byzantinische Zeitschrift, [S.I.], v. 107, n. 1, p. 175-220, 1 jan. 2014. Disponível em: <https://www.degruyter.com/view/j/byzs.2014.107.issue-1/bz2014-0009/bz-2014-0009.xml>. Acesso em: 05 jan. 2017.

ST-PIERRE, L.-P. L'identité romaine dans le discours impérial byzantin selon les œuvres et compilations de Constantin VII Porphyrogénète (913-959). 2017. 141 f. Mémoire (Maîtrise ès arts Histoire) - Faculté des lettres et sciences humaines, Université de Sherbrooke, Québec. Disponível em: <https://savoirs.usherbrooke.ca/handle/11143/11178>. Acesso em: 15 out. 2018.

SULEIMAN, Y. The Arabic Language and National Identity: A Study in Ideology. Edinburgh: Edinburgh University Press, 2003.

TØNNESSON, S.; ANTLÖV, H. (Ed.) Asian Forms of the Nation. London: Curzon Press, 1996.

TOUGHER, S. Periodization. In: LOUGHRAN, T. A practical guide to studying history: skills and approaches. London: Bloomsbury Academic, 2017. p. 31-45.

VAKALOPOULOS, A. Byzantium and Hellenism: Remarks on the Racial Origin and the Intellectual Continuity of the Greek Nation. Balkan Studies, Thessaloniki, v. 9, n. 1, p. 101-126, 1968. Disponível em: <https://ojs.lib.uom.gr/index.php/BalkanStudies/article/view/781/789>. Acesso em: 15 out. 2018.

VASILIEV, A. A. History of the Byzantine Empire: 324-1453. 2. ed. Madison: The University of Wisconsin Press, 1964. v. 1.

VEN, P. V. D. When Did the Byzantine Empire and Civilization Come into Being? In: ANNUAL MEETING OF THE AMERICAN HISTORICAL ASSOCIATION, 32., 1916, Cincinnati. Proceedings... Washington: American Historical Association, 1919. v. 1, p. 229-309. 


\section{artigos}

Guilherme Welte Bernardo

WIJNENDAELE, J. W. P. Apocalypse, Transformation or Much ado about nothing? Western scholarship and the Fall of Rome (1776-2008). Iris, Victoria, v. 24, p. 42-52, 2011. Disponível em: <https://classicsvic.wordpress.com/iris/volume24/> Acesso em: 25 nov. 2017. 